\title{
Engaging Klaus Nürnberger's interpretation of the doctrine of the Trinity
}

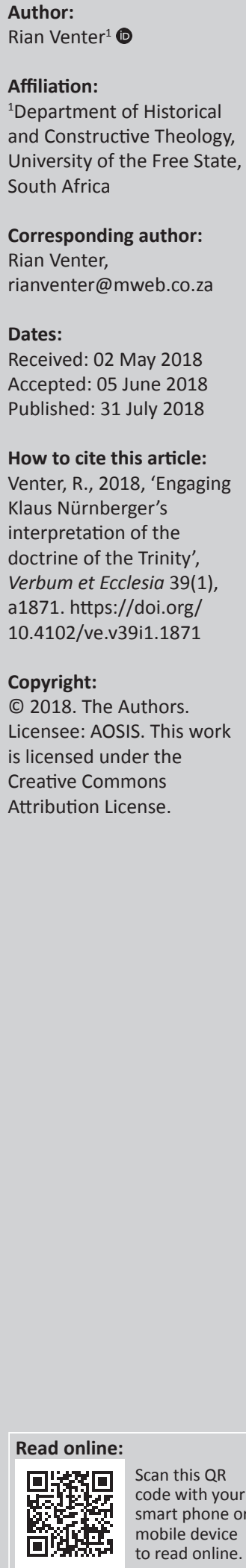

This article discusses the interpretation of the doctrine of the Trinity by K. Nürnberger from the perspective of an appreciation of his intellectual and theological accomplishment, especially as expressed in the publication of his systematic theology in 2016. Nürnberger's distinct understanding of the Trinity is mapped with reference to five perspectives: the structural place in the overall treatment of the Christian faith, an estimation of Patristic theology, the relative importance of the doctrine, the category for interpretation and, finally, the 'point' of the Trinitarian confession. To establish some form of evaluative frame of reference, the so-called Trinitarian Renaissance is briefly described. The article concludes with a preliminary evaluation, expressing concern about Nürnberger's negative view of the Patristic interpretation, the shift from a focus on God's nature and identity to human experience, a modernist conception about intelligibility and the dismissal of mystery and a general truncation of the heuristic potential of the doctrine.

Intradisciplinary and/or interdisciplinary implications: The article is an intra-disciplinary study. It addresses the view of a fellow systematic theological scholar (K Nürnberger). At stake is the impact of different research paradigms within the same discipline. In this case, the engagement is between the paradigms of realist-experiential versus critical-metaphysical. Different results emerge from this.

\section{Introduction}

\section{Appreciation}

When a comprehensive history of theology in South Africa is written, the name of Klaus Nürnberger will occupy a prominent place. The publication of his two-volume systematic theology - Faith in Christ Today - in 2016 was a significant theological achievement, the culmination of the intellectual work of a learned, creative and courageous thinker, and deserves careful and thorough engagement. In a time when the publication of peer-reviewed articles has become the primary mode of expression, this ambitious project that proposes a coherent and comprehensive vision of the Christian faith is quite impressive.

On a personal level, I still recall the excitement when Johan Heyns's Dogmatiek was published in 1978, and I discovered that Nürnberger already had completed his work - Sistematiese Teologie - in 1975. Something of that same excitement and surprise, I experienced in 2016. I did not expect that this would happen in South Africa with its small community of systematic theologians.

In this article, I would like to engage in a preliminary manner with Nürnberger's understanding of the doctrine of the Trinity. A theologian's understanding of God is obviously central and fundamental in any attempt to present an overview of the Christian faith. Much is determined by this. In addition, the 20th century has witnessed an amazing 'rediscovery' of the Trinity. In my engagement, I will try to capture the main contours of Nürnberger's view, refer to some outstanding features of the so-called Trinitarian Renaissance and conclude with comments and some questions.

\section{Main contours: Nürnberger on the Trinity}

All representation is problematic and, in a sense, a betrayal of the original, also in this case. A few basic perspectives or avenues are identified to get a mere glimpse of Nürnberger's approach. The focus is mainly on the treatment in volume 2 , chapter 19 , although references to other academic expressions by him will be made. The article contributed to the D. Smit Festschrift (Nürnberger 2011) provides a good summary of his views. 


\section{Place in the overall structure}

The contrasting situating of the discussion of the Trinity in their respective systematic projects by Schleiermacher ${ }^{1}$ and Barth (2005) alerted scholars to this critical structural move. Is it marginalised, does it function as some form of recapitulation or does it establish an optic that informs the rest of the discussion? The readers encounter in Nürnberger's work, apart from a few earlier references, a treatment of the Trinity only in volume 2, chapter 19 . It is noteworthy that he separates a discussion of the concept of God (chapter 12) from the interpretation of the Trinity. This structural move signals something fundamental - that the Trinity has another function than informing the identity of Godself. Basic to his approach to systematic theology is the category 'The living Word of God'. One would have expected a discussion of the Trinity already there, which is not present. $^{2}$

\section{Relation to Patristic theology}

The words employed by Nürnberger - 'messy picture', 'obscurity', 'incoherence' and 'bewilderment' (see N 2:292) ${ }^{3}-$ convey his fairly negative evaluation. The root of the problem according to him was the translation of the dynamic process found in the Bible into static ontological metaphysics' (N 2:292). Metaphors were reified. He also points out the problem of time and eternity inherent in the formulations (N 2:222). 'Paradox' is seemingly unacceptable to him. These formulations have become 'unintelligible', 'inaccessible' in terms of the contemporary world view. Nürnberger's dissatisfaction with Church Fathers should be carefully noted; he gives succinct treatment of this (2011:33). Three notions are central in his evaluation: speculation, reification and deduction. According to his reading of the Patristic narrative, abstract terms (metaphors) were given ontological status, and then unwarranted inferences were made from these assumptions (deduction and thus speculation). However, he acknowledges that this was a legitimate interpretation to accommodate the Hellenistic culture, but it does not make sense today (see the discussion in N 2:220-226); 'While we may identify with their intentions, we are not forced to agree with their formulations' (N 2:225). He even makes the dismissive statement that 'Experiential realists can be forgiven if they believe that the doctrine of the Trinity is beyond redemption' (Nürnberger 2011:40).

\section{Relative importance}

At least three evaluations of the Trinitarian doctrine can generally be identified in recent dogmatics: a formal discussion as part of the orthodox faith with no creative employment, a critical attitude and an application to the other doctrines as structural motif. Explaining at length the

1.See the discussion by Schüssler Fiorenza (2005) what the placing in the appendix could signify.

2.One cannot but be reminded by Webster (2003) that the Word is a function of the doctrine of God, and thus in a Christian sense of the Trinity. Ideally, a discussion of the Word of God should follow a treatment of the Trinity.

3.Referencing to $N 2$ indicates volume 2 of Faith in Christ Today by Nürnberger. evolution of the biblical concept of God, and demonstrating that the doctrine of the Trinity is 'one of these reconceptualisations', 'only one instance among other' (N 2:294, 326), Nürnberger clearly relativises the importance of it. He places this articulation on par with the God of Enlightenment, of modernity and of the global pluralist culture (N 2:297).

\section{Category for reinterpretation}

Because Hellenistic metaphysics have lost their traction, classical Trinitarian formulations should be replaced. Nürnberger proposes an 'experiential rendering of the Trinity' (N 2:299). The background here, which should be carefully considered, is his approach to doing theology 'experiential realism' - and his aversion to 'unnecessary sophistication' (N 2:47). His aim is 'simply to debunk unwarranted speculation in theology' (Nürnberger 2011:33). With this starting point, according to him, the doctrine expresses 'three essential aspects of a living Christian faith' (N 2:301). These three experiences correlate with God as Source and Destiny and a sense of derivation and accountability, with Christ and a sense of God's unconditional benevolence, and with the Spirit and the sense of God's presence. Nürnberger resists 'speculation' about God 'in Godself' and an ascription of 'mystery' to the doctrine. It must be made intelligible; he can even claim about his own interpretation 'There are no paradoxes and mysteries in this reconstruction' (Nürnberger 2011:42).

\section{Primary function or 'point'}

The Trinity plays an important role in most systematic theologies, but what it fundamentally signifies is not always clear. Jenson (1995) raises the question specifically about the 'point of Trinitarian theology'. ${ }^{4}$ In Nürnberger's work, the answer is quite clear and forms, arguably, the crux of his interpretation and of his contribution. It strictly has to do with theodicy. ${ }^{5}$ It is worthwhile to quote him at length here (N 2):

It is not always realised that the existential struggle between the experience of an ambiguous reality ascribed to creative divine power and the proclamation of a benevolent divine intentionality is the root of the Trinitarian doctrine. (p. 407)

The function of the doctrine of the Trinity is to affirm the identity of the God of creation and the God of benevolence as disclosed in Jesus Christ (N 2:302). The doctrine serves human 'ambiguous experience' in light of the tension between reality and benevolence. As such it has a 'protest character' and is 'struggle with God against God' (N 2:311, 312). Ultimately, the doctrine of the Trinity is "part of the doctrine of Christ', it explicates what happened in Christ (N 2:303).

4.For Jenson (1995:42), 'the point' is 'that the biblical story about God and us is true of and for God himself'.

5.Nürnberger's sermon - A new song (Currents in Theology and Mission 1992, 19/2) is also instructive in this regard. Here, he refers to two forms of dialectic in the doctrine of the Trinity, between mystery and revelation, and Creator and Redeemer. 


\section{Some reference: 20 th century Trinitarian Renaissance}

To engage the interpretation of Nürnberger, some form of reference is required and the most obvious one will arguably be the developments during the 20th century with the so-called Trinitarian Renaissance, which is regarded by some as one of the most significant theological shifts of our time (Grenz 2004:1). Excellent resources are available to assist one to navigate this terrain, and The Oxford Handbook of the Trinity (Emery \& Levering 2011), which provides a good overview of the biblical, historical, doctrinal and constructive scholarly developments, could be singled out.

What gave the impetus could be debated. Conventionally, the new interest is connected with the two Karls - Barth and Rahner. Both made seminal contributions with their respective work on the prominence of the Trinity as part of revelation in the traditional prolegomena and the re-visioning of the attributes, and the formulation of the axiom with regard to the relationship of the economic and immanent Trinity. The retrieval may go much further back, and the impact of German Idealism, especially Hegel with a new appreciation for history (Sanders 2012:22), and the quest for new relational categories of thought beyond substantialist ones (Shults 2005:5) should be acknowledged.

Kärkkäinen (2009), who wrote extensively on Trinitarian developments, may be a sure guide in this complex terrain. He identifies three major developments: the new appreciation for communion ways of thinking, the exploration of the practical implications of the Trinitarian confession and the contextualisation in different cultural contexts. He considers the question of the relationship between economic and immanent Trinity as the heart of the current debate. In his recent book on God, the Dutch scholar Van de Beek (2017:248-255) also identifies the turns to history and to relationality key to the new developments.

At stake here is the realisation that the Trinitarian confession is the specific manner to name the identity (being) of the Christian God, that ultimate reality is not monadic but relational, and that this insight carries analogically immense implications for the articulation of the Christian vision and for social life.

What remains intriguing is the productive consequences of the retrieval. Far from being perplexing and paralysing, the doctrine has led to renewed scholarly study of persons such as Arius, the Cappadocians, Augustine, Richard of St Victor, Edwards, to new reconstructions of doctrines like anthropology and ecclesiology, and to imaginative reenvisionings of identity questions and social ethics. The confession of a deity who is simultaneously one being and three persons, of one who became man, and who died on a cross unleashed the post-modern imagination to connect questions of alterity, gifting, hospitality and the impossible to the sacred.
In no way should the impression be created of a uniform movement. The diversity, plurality and contestations among Trinitarian thinkers are too stark. For example, how Boff (1988) links the Trinity to politics differs drastically from the approach of Tanner (2012) and this difference of opinion about 'God as model' versus 'participating in God's life' generated a vast number of publications.

\section{Observations, comments, questions: Reaction to Nürnberger}

Nürnberger deserves credit for his courage to question the intelligibility of classical Trinitarian formulations, and for his creative and in a sense innovative reinterpretation of the function of the doctrine. His discussion confronts the readers to face fundamental matters. The relation between an experience of creation as threatening and an assertion of an underlying benevolence remains a complex challenge.

I submit some preliminary comments to Nürnberger's Trinitarian reflection. An in-depth analysis should investigate the development in the 40-year lapse between his Sistematiese Teologie and the recent Faith in Christ Today, and it should explore fully his treatment of Christology and Pneumatology which would finally impact his understanding of the Trinity. Theological decision made there finally determines the shape of his Trinitarian view. His approach to doing theology and his understanding of the notion of 'Word of God' should also be carefully factored into a discussion. The separation of the concept of God (chapter 12) and a discussion of the Trinity (chapter 19) is critical. Other articles published on the aspects of the doctrine of God and the Trinity should also be taken into account. The fact that he comes from a Lutheran background should also be remembered in a complete evaluation of his theology:

- No doctrine of God can be written today without a genealogical account. However, genealogies can be construed and utilised differently. One can see this quite clearly in the recent work by Aslan - God: A Human History (2017) with its atheistic conclusion. It is a question whether the Trinitarian reconceptualisation is merely another one on par with a host of others which Nürnberger identifies. Did a radical redefinition of monotheism not crystallise here which, for the Christian faith, remains a decisive identification of the divine? The identity could be hermeneutically translated with different categories of thought, but the ontic structure of the One and the Many continues, and the language of 'nature' and 'person' may still be fairly sufficient to name unity and differentiation. One misses an appreciation of this drastic caesura in perceiving the divine in Nürnberger's work. One cannot escape the impression that Jesus Christ and the Holy Spirit are manifestations to characterise God's work, and not his nature.

- The question about the relative status of the reconceptualisation obviously interfaces with a valuation of the Patristic period and its accomplishments. South African systematic theologians have never been great 
Patristic scholars. The more recent work, for example, on Arius (Williams 2002), on Nicene theologians (Ayres 2004), on empire and Nicea (Rieger 2007) and on the Cappadocians (Zizioulas 2008), gives an impression of the particular intellectual accomplishment of the early theologians. The creativity to think relation as primary ontological category, to think in terms of perichoresis and to think change in terms of divinity may remain achievement of enduring value. The traditional Hellenization thesis is critically evaluated today (Markschies 2012) and the Fathers as biblical exegetes are greatly stressed. The narrative from the New Testament to Nicea can be construed in a different manner from that of Nürnberger's. More was at stake than reification, deduction and ultimately speculation as Nürnberger suggests. One cannot escape the impression, when reading Nürnberger, that the Fathers had it all wrong. For example, the role of worship as impetus for reflection is greatly appreciated today (Wilken 1982:25). ${ }^{6}$ May be, a more nuanced, more scholarly and historically informed and less dismissive attitude is called for today. ${ }^{7}$

- The Trinitarian confession that the church believes in one God revealed as three persons - has always been an emphatic statement about God's identity. In the Trinitarian Renaissance with its many exponents, this basic focus has even been intensified: God's eternal reality is complex, communal and relational. The way God has revealed Godself is how God is in God's eternal reality. This is the 'point' of the Trinitarian doctrine. Van de Beek (2017:274), who is quite critical of many 20th-century interpretations, in his recent work stresses precisely this insight: it is about the divinity of Jesus Christ. The question is, and this seems to me is the crux, when reading Nürnberger and when I am trying to understand him: does he also say this? Does this not entail more than asserting the 'manifestation' of divine benevolent intentionality? It seems to me a drastic shift takes place in his theology. He is not interested in 'God as such', only in 'God for us' (see discussion in N 2:4). One can easily brush the problem off with 'we have no business in the internal workings of the Trinity', but the early Father were acutely aware that the experience of Jesus's resurrection had immense ramifications for a notion of a 'solitary' God and we find early attempts to speak about differentiations within the Godhead (Wilken 1982:23). This was inevitable. The problem of the immanent or economic Trinity, ${ }^{8}$ although he does not employ these terms, assumes a specific trajectory in Nürnberger's construal. The Trinity becomes a statement to resolve tension, to give expression to human experience. The Trinity is about 'reassurance'

6.The seminal work by Hurtado (2003) on the early worship of Jesus makes it clea why a radical rethinking of Jewish monotheism was inevitable for the Church Fathers.

7.The excellent overview of the state of scholarship by Ayres and Radde-Gallwitz (2008) conveys a sense of the complex process of rethinking the nature of God. This same impression is also conveyed by another treatment of scholarly development - Coakley (2007). She mentions that the 'pro-Nicene' commitment was 'undergirded by a profound sense of mystery' (p. 136).

8.Several configurations are proposed by theologians today; Baik (2011) identifies seven positions. A scholar like Molnar (2002) strongly argues for the importance of the immanent Trinity.
(N 2:290). His explicit experiential reading can hardly allow a different interpretation. An experience of origin, destiny and benevolence should be kept together and be made intelligible for humans. One can approach this conclusion from a different angle: the creativity and the benevolence, he associates with God, do not result from God's Trinitarian life; they are not manifestations of God's eternal fecundity and God's eternal love. His discussion of God as the 'transcendent Source and Destiny of reality' takes place way prior to a consideration of the Trinity (this is the implication of the separation of chapters 12 and 19). Should origin and benevolence not be argued from the reality and identity of the Triune life, and find their possibility in the life of God? One is prompted to raise the following question: what difference does the Trinity make to our understanding of God? Sanders (2007:35) notes that 'The task of doctrine of the Trinity is to describe the connection between God and the economy of salvation'. Nürnberger's aversion to ontology comes with a price.

- After we have started to realise that words work with the so-called 'linguistic turn', that they have effects, theologians have developed an antenna for performativity. Nürnberger wants to dispel an 'unfathomable mystery' to address ambiguity in human experience. The Trinitarian Renaissance, so it seems to me, with its focus on the relational quality of God's being, has not rendered the mystery fathomable, but deepened it, and in this process unleashed intellectual and social energy to rethink God, for example, in terms of space and beauty (see Barth's discussion of the 'perfections' of God, 1957), to rethink ourselves in terms of communion and to rethink society in terms of ex-stasis, kenosis, unity or diversity. Traditional metaphysics have not paralysed, but mobilised, stimulated and motivated. Paradoxes do not only obscure, they can also generate imaginative thinking and action. My fear is that Nürnberger's proposal may inhibit the immense productive potential the Trinity as Christian redefinition of the divine may have, and ultimately its heuristic possibilities for theology. There is a striking persistence in his discussion of the Trinity that it must be 'understood', and that it does not entail a 'mystery'. Unavoidably, one worries that this sentiment expresses a typical (reductionist) modernist sentiment. Consistently, the Trinitarian confession has intensified a realisation of the hiddenness and the mystery of God; this is a recurring motif throughout the history of theology. In contemporary, Trinitarian thought that the close connection with apophatism is well known and the insistence is rather to move deeper into union with the Triune Mystery than to render God 'intelligible' (see Hunt 2010 on the role of the Trinity in the life of mystics). A scholar like Kasper (1983) even places a retrieval of the Trinity, along fairly orthodox lines, in the frame of a response to a-theism. A sacrifice of 'mystery' will not make the Trinity more attractive to secular critics.

- Experience has claimed a methodological space in theology and will most likely grow in importance in future. Nürnberger's explicit choice of such an approach deserves careful scrutiny. In his Trinitarian theology, the referent 
is clearly singular: the contradiction between creation and benevolence. This exhausts the experience. In other versions of Trinitarian theology, 'experience' functions differently, as hermeneutical pre-understanding to bring greater understanding and ultimately change. In face of Triune Mystery, experiences of economic injustice, religious diversity, cultural uniqueness and of gender identity, to name only a few, allow for a divine recognition and subsequently for a new self-understanding. ${ }^{9}$ Nürnberger's claim that the classical Trinitarian doctrine is 'no longer functional' runs counter to the experience and Trinitarian 'sense-making' of a rather large number of theologians and 'ordinary' believers. This is the amazing insight generated by the Trinitarian Renaissance - the classical confession resonates with an immense scope of experiences. Theodicy can be addressed Trinitarianly, ${ }^{10}$ but should not absorb the doctrine, as the only avenue to human experience.

\section{Conclusion}

\section{Admiration and concern}

One cannot but admire a number of features of Nürnberger's interpretation of the Trinity. The intellectual courage to go against the grain is striking; he critiques the Early Fathers and resists the developments of the 20th century. His alternative exhibits a remarkable coherence and this he advocates with a sensitive philosophical, apologetical and pastoral antenna. At work is clearly a thinker and theologian with exceptional ability. The attention in his approach to creation and benevolence and to theodicy should be considered a lasting contribution to Trinitarian theology.

At the same time, one cannot but express concern about the general texture of his interpretation. It would have been fairly easy to employ labels to characterise his work, labels borrowed from the Early Church and the views considered unorthodox, or from conventional evaluations of the 19th century liberal theology. I feel uneasy with this approach and will not go this way. What can be contested in his construal is his split in treatment of God in the systematic theology; the initial depiction of God's identity is not Trinitarian. The consideration of an 'immanent Trinity' is not 'speculation'; the treatment has a necessary theological function for divine work ad extra. The very 'being', the very identity of God, is an event of personal relations. This is the mystery of God, and ultimately of created reality. The consistent charge of 'speculation' or 'unintelligibility' is nothing but a discrediting rhetorical devise. Orthodox Trinitarian theology has an astonishing vitality and potential to subvert traditional metaphysics, selfconstructions and social sense-making. To this, a massive volume of literature can testify, which cannot be brushed off.

The significance of a great scholar's theology cannot be measured by its popular acceptance. On the contrary, work that penetrates to the heart of life, to the deepest of human

9.See, for example, the Trinitarian explorations of Meeks (1989), Ogbonnaya (1994), Heim (2001) and Tonstad (2016).

10.See proposal by Van den Brink (1990). questions, will generate discussion, dissent and contestation, and Nürnberger's Trinitarian theology surely does this. It stimulates further discussion and prompts a return to one's own positions for further self-reflection. A word of sincere appreciation to Klaus Nürnberger is fully warranted.

\section{Acknowledgements Competing interests}

The author declares that he has no financial or personal relationships that may have inappropriately influenced him in writing this article.

\section{References}

Aslan, R., 2017, God: A human history, Bantam, London.

Ayres, L., 2004, Nicaea and its legacy: An approach to fourth-century trinitarian theology, Oxford University Press, Oxford.

Ayres, L. \& Radde-Gallwitz, A., 2008, 'Doctrine of God', in A.A. Harvey \& D.G. Hunter (eds.), The Oxford handbook of early Christian studies, pp. 864-885, Oxford University Press, Oxford.

Baik, C-H., The holy Trinity: God for God and God for us: Seven positions on the immanent-economic trinity relation in contemporary Trinitarian theology, Pickwick, Eugene, OR.

Barth, K., 1957, Church Dogmatics 2/1. The doctrine of God, T\&T Clark, Edinburgh.

Boff, L., 1988, Trinity and society, Burns \& Oates, Kent.

Coakley, S., 2007, 'Disputed questions in Patristic Trinitarianism', Harvard Theological Review 110(2), 125-138.

Emery, G. \& Levering, M. (eds.), 2011, The Oxford handbook to the Trinity, Oxford University Press, Oxford.

Grenz, S.J., 2004, Rediscovering the triune God: The Trinity in contemporary theology, Fortress, Minneapolis, MN.

Heim, S.M., 2001, The depth of the riches: A Trinitarian theology of religious ends, Eerdmans, Grand Rapids, MI.

Heyns, J.A., 1978, Dogmatiek, N.G. Kerkboekhandel Transvaal, Pretoria.

Hunt, A., 2010, The Trinity: Insights from the mystics, Liturgical Press, Collegeville, PA.

Hurtado, L.W., 2003, Lord Jesus Christ: Devotion to Jesus in earliest Christianity, Eerdmans, Grand Rapids, MI.

Jenson, R.W., 1995, 'What is the point of Trinitarian Theology?' in C. Schwöbel (ed.) Trinitarian theology today: Essays on divine being and act, pp. 31-43, T\&T Clark: Edinburgh.

Kärkkäinen, V-M., 2009, 'The trajectories of the contemporary "Trinitarian Renaissance" in different contexts', Journal of Reformed Theology 3, 7-21. https:// doi.org/10.1163/156973109X403697

Kasper, W., 1983, The God of Jesus Christ, SCM, London.

Markschies, C., 2012, 'Does it make sense to speak about "Hellenization of Christianity" in antiquity?', Church History and Religious Culture 92, 5-34. https:// doi.org/10.1163/187124112X621581

Meeks, M.D., 1989, God the economist: The doctrine of God and political economy, Fortress, Minneapolis, MN.

Molnar, P.D., 2002, Divine freedom and the doctrine of the immanent Trinity, T\&T Clark, London.

Nürnberger, K., 1975, Sistematiese Teologie, Teologise Boekreeks, Genadendal.

Nürnberger, K., 1992, 'A new song', Currents in Theology and Mission 19(2), 85-88.

Nürnberger, K., 2011, 'An experiential approach to time and the Trinity', in L. Hansen, N. Koopman \& R. Vosloo (eds.), Living theology: Essays presented to Dirk J Smit on his sixtieth birthday, pp. 32-44, Bible Media, Wellington.

Nürnberger, K., 2016a, Faith in Christ today: Invitation to systematic theology, vol. 1, Cluster Publications, Pietermaritzburg.

Nürnberger, K., (N 2), 2016b, Faith in Christ today: Invitation to systematic theology, vol. 2, Cluster Publications, Pietermaritzburg.

Ogbonnaya, A.O., 1994, On communitarian divinity: An African interpretation of the Trinity, Paragon House, New York.

Rieger, J., 2007, Christ \& empire: From Paul to postcolonial times, Fortress, Minneapolis, MN.

Sanders, F., 2007, 'The Trinity', in J. Webster, K. Tanner \& I. Torrance (eds.), The Oxford handbook of systematic theology, pp. 35-53, Oxford University Press, Oxford.

Sanders, F., 2012, 'The Trinity', in K.M. Kapic \& B.L. McCormack (eds.), Mapping modern theology, pp. 21-45, Barker, Grand Rapids, MI.

Schüssler Fiorenza, F., 2005, 'Schleiermacher's understanding of God as triune', in J. Mariña (ed.), The Cambridge companion to Friedrich Schleiermacher, pp. 171-188, Cambridge University Press, Cambridge. 
Shults, F.L., 2005, Reforming the doctrine of God, Eerdmans, Grand Rapids, MI.

Tanner, K., 2012, 'Social Trinitarianism and its critics', in R.J. Woźniak \& G. Maspero (eds.), Rethinking Trinitarian theology, pp. 368-386, T \& T Clark, London.

Tonstad, L.M., 2016, God and difference: The Trinity, sexuality, and the transformation of finitude, Routledge, New York.

Van de Beek, A., 2017, Mijn Vader, uw Vader: Het spreken oor God de Vader, Meinema Utrecht.
Van den Brink, G., 1990, 'Theodicee en Triniteit', Theologia Reformata 33, 7-27.

Webster, J., 2003, Holy Scripture: A dogmatic sketch, Cambridge University Press, Cambridge.

Wilken, R.L., 1982, 'The resurrection of Jesus and the doctrine of the Trinity', Word \& World 2(1), 17-28.

Williams, R., 2002, Arius: Heresy and tradition, 2nd edn., Eerdmans, Grand Rapids, MI. Zizioulas, J., 2008, Lectures in Christian Dogmatics, T\&T Clark, London. 